\title{
Revising the Need to Improve Ecological Situation in the Mining Region
}

\author{
Natalia Egorova ${ }^{1, *}$, Natalia Zaruba ${ }^{1}$, and Dusan Kudelas ${ }^{2}$ \\ ${ }^{1}$ T.F. Gorbachev Kuzbass State Technical University, 650000, 28 Vesennyaya street, Kemerovo, \\ Russia \\ ${ }^{2}$ Technical University of Kosice, Faculty of Mining, Ecology, Process Control and Geotechnologies, \\ Letná 9, 04200 Kosice, Slovak Republic
}

\begin{abstract}
In present-day conditions the main goal of social and economic development of any territory is the growth of living standards including improvement of ecological situation by carrying out nature protection measures. Increase of negative impact on environment and sometimes uncivilized use of natural potential of the region are the main reasons why society concerns the problems of environment preservation. Improvement of ecological situation is one of the most important factors of development of the region now, at the same time providing balance of interrelation between public needs and natural resources. As a result the question of the need to provide conditions for improvement of environment in a region, especially in a coal-mining region, in the course of its development, becomes more and more urgent. That's why environmental monitoring should become one of the instruments of execution of such approach, which today, undoubtedly, means a lot in the solution of environmental problems, however is not always systematic and does not consider all features of a mining region. The need of careful studying and forecasting of an ecological state of the coal-mining region becomes logical and obvious.
\end{abstract}

\section{Introduction}

Today the negative anthropogenous impact on ecology of coal-mining regions becomes especially noticeable and gains global character. It is caused, first of all, by the fact that enterprises of the coal-mining industry, which are large subjects of economic activity in the region, cause damage to the environment, polluting it in the process of mining of natural resources (coal) in big amount. However in the current situation in foreign policy and foreign economy the government especially needs to keep social and economic stability, at the same time stimulating growth of economy of the country and its regions.

Therefore, coal-mining enterprises still remain to be top-priority for national economy as the importance of energy raw material resources is obvious for other spheres of economy. So, the state and the coal enterprises need to develop new administrative and technological approaches to solution of environmental problems in the coal-mining region.

\footnotetext{
${ }^{*}$ Corresponding author: egorovann@list.ru
} 
Under these conditions the possibilities of environmental monitoring are especially relevant for the research. In our opinion it is one of the most significant directions in environmental protection. Environmental monitoring is complex and is carried out for the purpose of control of not only universal environmental tendencies but also environment in those territories to which ecological damage is caused owing to carrying out commercial developments there, as it happens in Kuzbass. Prevention or reduction of negative consequences for the region with the help of a system approach to the environmental monitoring management is the main objective for the Kemerovo region.

\section{Discussion and Debates}

The considerable attention is paid to the questions of preservation and improvement of ecological situation in the coal-mining region today. We consider interesting the works of such scientists as: Sribas Goswami, Bagchi A, Bose A. The problem is widely discussed in different countries and today gains global character $[1-3,7-10,13]$.

Taking into account a number of features of the coal-mining region, it should be noted that the impact of coal industry and all other industries connected to it on surrounding environment inevitably causes its negative change. Coal mining does not observe the existing condition of ecological situation in the regions with a large number of industrial facilities (mines, open pits, washing plants), and also keep damaging the environment.

These are examples of the coal mining influence: expropriation of the territories necessary for agricultural works, soil dehydration, deterioration in condition of underground and surface water, flooding and bogging of subsided areas, emission of harmful substances, change of microclimate of the coal-mining region.

Carrying out mining operations causes serious ecological damage to the environment which is amplified by other negative factors because of the influence of other industries developing in the region (metallurgical, chemical industries, coal enrichment, etc.)

In other words, technogenic processes, running at operation of various objects of mining production, deteriorate the environmental state. Negative impact of coal-mining enterprises on the region ecology happens directly at coal mining. Hydromineral and ecological resources, such as soil, water, air, are polluted. Besides, there is a thermal pollution of biosphere, electromagnetic and radioactive influence.

All above can be directly referred to such coal-mining region as the Kemerovo region. Ecological situation in the Kemerovo region today in general is rather strained. It is confirmed by the fact that mining and processing of coal, which operation is the main condition of regional sustainable development, despite continuous efforts of the environmental protection management for the purpose of its preservation, still make negative impact on the ecology.

The Kemerovo region owing to existence of such mineral as coal remains an industrial region which main industry is coal mining. In the region territory the most part of business assets of Western Siberia is concentrated, a variety of mineral resources allows to carry out not just coal mining, but also to develop all industries connected to these raw materials.

It is necessary to emphasize that the influence of activity of industrial enterprises on the mining region environment has mainly a negative character. The dominating place of coal industry in the economic structure of the Kemerovo region defines an intensive development of industrial sector of economy. Activity of coal industry enterprises located in the region has coal-mining consequences which are followed by adverse effect on the environment.

Today the Kemerovo region is leading in coal mining not only in Russia, but also in the world, the share of coal industry makes more than $30 \%$ of all industrial production of the 
region, but coal is extracted by open and underground ways that inevitably negatively influences the condition of ecology of the region.

It is necessary to understand that Kuzbass is one of the most ecologically polluted regions of Russia today, and it is connected, first of all, with emissions of polluting substances in the environment by coal-mining enterprises. Today the most significant environmental problems of Kuzbass, in our opinion, are: pollution of natural reservoirs, air pollution, lack of logistics when recycling, pollution of soils, forest degradation.

The diversified national economy and concentration of raw productions cause formation of large volumes of production wastes and consumption. Industrial production is followed by formation of solid waste, emissions in the atmosphere, pollution of surface and underground water, degradation of lands. The greatest damage is caused, of course, by mining enterprises $-97.04 \%$. The greatest contribution to pollution of the atmosphere (on gross emissions) is made by the enterprises of coal industry, from which the main sources of polluting substances are open pits (open way of coal mining). More than $50 \%$ of emissions of polluting substances in the air are the emissions from mining. It is the indicator demonstrating negative impact of coal-mining enterprises on the region ecology. Extracting only one ton of coal, a coal enterprise creates 3-20 tons of solid waste and emits $5-25 \mathrm{~m}^{3}$ of methane into the atmosphere.

Mining facilities in the region damaged and removed from agricultural production more than 80 thousand hectares of fertile lands, more than 300 small rivers of the region disappeared.

During the recent years the share of polluted water, running from coal-mining enterprises in surface water bodies, has been growing and made, including 2018, more than $30 \%$. Also polluted sewage arrives from the enterprises engaged in collecting, cleaning and distributing of water $(37.0 \%)$, chemical production $(13.7 \%)$. The less volume of polluted water is dumped as a result of production, transfer and distribution of electric power $(7.5 \%)$ and metallurgical production (7.0\%). However, we understand that coal and connected industries save a negative priority in causing damage to water resources of the region. The ecological condition of land resources of the Kemerovo region is also a subject for analysis and monitoring, because land is the main mean of production for agriculture and forestry, and is also a territorial space for human life and activities, placement of enterprises and organizations of all sectors of the national economy.

Coal exploration and production, technogenic emissions, urbanization of territories render anthropogenous loads for natural resources, forcing deterioration in ecology of the region. As a result of mining production the most part of territories of the Kemerovo region is exposed to big man-caused impact.

In these territories there are processes of soil pollution, the places of pollution by toxic substances are formed, biological efficiency of lands suitable for agriculture decreases. More than 75 thousand hectares of lands are disturbed completely (fertile layer is lost).

Within realization of a uniform sectoral eco-economic policy of stimulation of ecologically sustainable development of the coal-mining region and along with the efforts to stabilize activity of existing and new enterprises of coal industry, it is necessary to overcome the whole complex of ecological consequences of their activity. In our opinion the process of improvement of the region ecology, taking into account elimination of negative ecological results from the coal enterprises' activity, demands more efficient approach, including to the environmental monitoring management, in order to decrease negative influence on the environment. It is true that today carrying out environmental monitoring is codified by law, however, the enterprises, without regard to attempts of the authorities to improve ecological situation, still continue to carry negative impact.

Understanding monitoring as studying and forecasting of an environmental state and its possible change under the influence of anthropogenous factors, we can designate it as one 
of the most important directions of environmental policy of the coal-mining region. Environmental monitoring is a full range of measures, carried out according to sciencebased methods, directed to systematic supervision of the environmental state, to its assessment, forecasting of possible changes under the influence of different factors, including anthropogenous.

Collecting and regular analysis of reliable information about condition of environment and objects, and also drawing up forecasts of change of ecological situation in the region are the purpose of such monitoring. On the basis of the provided data the further decisionmaking in the field of environmental activity is carried out for the purpose of development of economic policy of the mining region taking into account ecological factors. The system of environmental monitoring should represent, in our opinion, a set of mutually coordinated structures of management, coal-mining enterprises, technical and information means and inhabitants of the region whose activity is also important (see fig. 1).

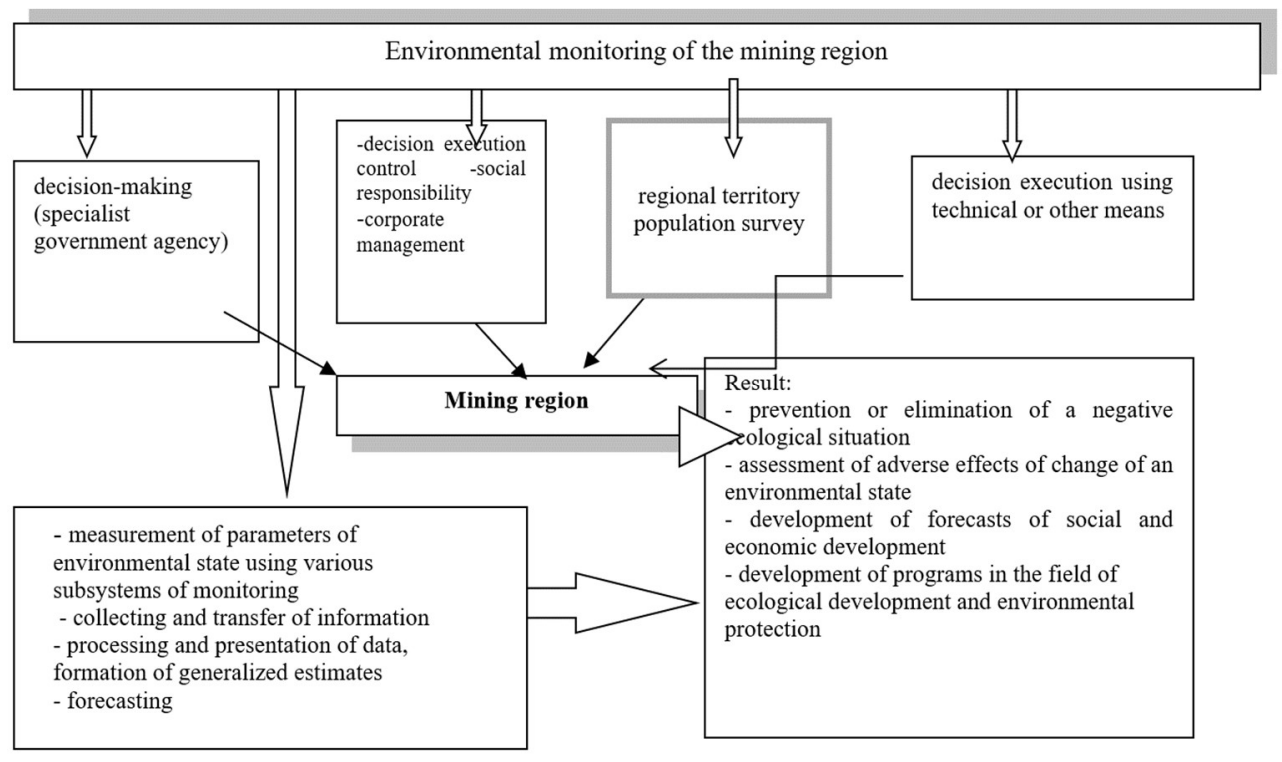

Fig. 1. Management system of environmental monitoring of the mining region.

Environmental monitoring plays an important role, analyzing anthropogenous influence, particularly of industrial enterprises, on ecology of the coal-mining region, at the same time performing the main objective - improvement of its ecological state.

\section{Conclusions}

We consider that coal mining makes considerable negative impact on economic, social and ecological conditions of the regions carrying out mining activity. Mining negatively influences ecological systems in general. It is important to understand it for an assessment of potential adverse effects of production on ecology of the coal-mining region.

Summarizing the above, it is possible to note that in the Kemerovo region the question of change of the approach to environmental monitoring is burning. The system approach to the environmental monitoring management of the coal-mining region should create the main directions of environmental policy taking into account the opinion of people on ecological situation in the territory of their accommodation, requirements of standard and legal base in the field of ecology and preservation of the environment, work of specialist 
government agencies, and, of course, to lean on social and ecological responsibility of coal enterprises.

In that case it is possible to provide stable improvement of ecology and quality of life of people respectively and to save natural heritage as a source of further development of the region.

\section{References}

1. S. Goswami, Research, Engineering and Management, 4:66, 79-84 (2013)

2. A. Bagchi, R.N. Gupta, Surface blasting and its impact on environment (IPDP, Varanasi, 1990)

3. A.K. Biswas, S.B.C. Agarwal, Environmental Impact Assessment for Developing countries (Butterworth Heinemann Ltd., Oxford, 1992)

4. A.K. Bose, B. Singh, Impact assessment and Management, 4, 243 (1989)

5. T.E. Downing, J. Moles, I. McIntosh, Indigenous Peoples and Mining: Strategies and Tactics for Encounters (IIED, London, 2002)

6. K.M. Ghose, Effect of opencast mining on soil fertility Centre of mining environment (I.S.M, Dhanbad, 2004)

7. N. Zaruba, N. Egorova, P. Kosinskij, E3S Web Conf., 15, 04003 (2017)

8. N.A. Zaruba, N.N. Egorova, Coal in the 21 st Century: Mining, Processing and Safety, 39 (2016)

9. N. Egorova, N. Zaruba, T. Jurzina, V. Tumin, E3S Web Conf., 41, 02001 (2018)

10. S. Nish, S. Bice, New Directions in Social Impact Assessment. Conceptual and Methodological Advances (Edward Elgar Publishing Limited, London, 2012)

11. P. Penz, J. Drydyk, P. Bose, Displacement by Development. Ethics, Rights and Responsibilities\| (Cambridge University Press, Cambridge, 2011).

12. T. Jurzina, N. Egorova, N. Zaruba, P. Kosinskij, E3S Web Conf., 21, 04010 (2017)

13. F. Walsh, C. Wood, The Environmental Assessment of opencast coal mines (University of Manchester, Manchester, 1991) 